\title{
PENGGUNAAN OBAT YANG BENAR (DAGUSIBU) : GEMA CERMAT DAN PELATIHAN TENTANG OBAT KELUARGA DI KOTAGEDE YOGYAKARTA
}

\section{THE CORRECT USE OF MEDICINES (DAGUSIBU) : ECHO FEATURES AND TRAINING ON FAMILY MEDICINE IN KOTAGEDE YOGYAKARTA}

\author{
Dyah Anggraeni Budhi Pratiwi \\ STIKes Surya Global Yogyakarta \\ Email : dyahanggraeni2612@gmail.com
}

\begin{abstract}
ABSTRAK
Obat pada dasarnya merupakan bahan yang hanya dengan takaran tertentu dan dengan penggunaan yang tepat dapat dimanfaatkan untuk mendiagnosa, mencegah penyakit, menyembuhkan atau memelihara kesehatan. Obatobat bebas yang dapat dibeli tanpa resep dokter di apotek dan toko obat dapat mendorong untuk pengobatan sendiri. Semakin banyaknya obat yang beredar di pasaran memberikan alternatif pilihan yang luar biasa banyaknya bagi masyarakat yang kadang-kadang pemilihannya bukan didasarkan pada pertimbangan ilmiah, tetapi hanya pertimbangan kebiasaan atau saran dari kerabat. Hal ini membahayakan bagi masyarakat, karena penggunaan suatu jenis obat selalu diikuti dengan adanya efek samping yang terkadang akibat lebih jauhnya tidak terpikirkan oleh penggunanya. Terlebih fanatisme terhadap suatu merk banyak terjadi di masyarakat. Maka, dilakukan penyuluhan untuk Meningkatkan pengetahuan masyarakat terhadap penggunaan obat yang benar sesuai DAGUSIBU. Penyluhan dan pelatihan tentang obat menjelaskan dan mensosialisasikan Gerakan masyarakat cerdas menggunakan obat (GEMA CERMAT). Penggolongan obat berdasarkan nama obatm bentuk sediaan, cara penggunaan, penandaan obat dalam kemasan dan efek dari obat. Cara pengunaan obat yang benar, penandaan yang ada dalam kemasan obat, cara pembelian obat yang benar, cara membaca dan memahami informasi pada kemasan obat, pengunaan obat meliputi aturan pakai, waktu minum obat, efek samping dan kontra indikasi, tujuannya adalah untuk mengurangi kesalahan dalam pengobatan dan memberikan pengetahuan tentang pengobatan yang rasional. Cara penyimpanan obat agar terhindar dari kerusakan obat serta cara pembuangan obat yang benat.
\end{abstract}

Kata Kunci : Masyarakat, Dagusibu, Penyuluhan

\begin{abstract}
The drug is basically a material that only with a certain amount and with proper use can be used to diagnose, prevent diseases, heal or maintain health. The drug-free medicine which can be purchased without a doctor's prescription in pharmacies and drug stores can encourage for the treatment itself. The increasing number of drugs circulating in the market provide an alternative choice is a tremendous amount for the community that sometimes the election is not based on scientific considerations, but only the consideration of the habits or the advice of relatives. It is dangerous for society, because of the use of a type of drugs always followed with the side effects sometimes caused by more away is unthinkable by its users. Especially bigotry against a brand many occur in the community. Then, conducted outreach to Increase public knowledge of the correct use of medicines according DAGUSIBU. For and training about the drug explaining and disseminating the community Movement intelligent use of drugs (ECHO PLEASE). Classification of drugs based on the name of the obatm dosage form, method of use, marking of the drug in the packaging and the effect of the drug. How to use drugs properly, marking that exists in the packaging of the drug, how to purchase the correct medications, how to read and understand the information on drug packaging, the use of the drug include dosage, time the medication, side effects and contra indications, the goal is to reduce errors in treatment and to provide knowledge about the treatment rational. How to storage of the drug in order to avoid damage of the drug as well as how to discharge a drug that has
\end{abstract}

Keywords : Community, Dagusibu, Counseling 


\section{PENDAHULUAN}

DAGUSIBU (Dapatkan, Gunakan, Simpan, Buang) merupakan program Gerakan Keluarga Sadar Obat yang diprakarsai oleh Ikatan Apoteker Indonesia dalam mencapai dan kesasaran masyarakat terhadap penggunaan obat dengan benar (PP IAI, 2014). Kemajuan yang pesat di bidang kedokteran dan farmasi telah menyebabkan produksi berbagai jenis obat meningkat sangat tajam. Setiap perilaku kesehatan dapat dilihat sebagai fungsi pengaruh kolektif salah satunya dari faktor predisposisi antara lain pengetahuan, sikap, dan persepsi (ISFI, 2008).

Obat pada dasarnya merupakan bahan yang hanya dengan takaran tertentu dan dengan penggunaan yang tepat dapat dimanfaatkan untuk mendiagnosa, mencegah penyakit, menyembuhkan atau memelihara kesehatan (Depkes RI, 2008). Obat adalah racun yang jika tidak digunakan sebagaimana mestinya dapat membahayakan penggunanya, tetapi jika obat digunakan dengan tepat dan benar maka diharapkan efek positifnya akan maksimal dan efek negatifnya menjadi seminimal mungkin (ISFI, 2008). Oleh karena itu sebelum menggunakan obat, harus diketahui sifat dan cara pemakaian obat agar penggunaannya tepat dan aman (Depkes RI, 2008).

Obat-obat bebas yang dapat dibeli tanpa resep dokter di apotek dan toko obat dapat mendorong untuk pengobatan sendiri. Semakin banyaknya obat yang beredar di pasaran memberikan alternatif pilihan yang luar biasa banyaknya bagi masyarakat yang kadangkadang pemilihannya bukan didasarkan pada pertimbangan ilmiah, tetapi hanya pertimbangan kebiasaan atau saran dari kerabat. Hal ini membahayakan bagi masyarakat, karena penggunaan suatu jenis obat selalu diikuti dengan adanya efek samping yang terkadang akibat lebih jauhnya tidak terpikirkan oleh penggunanya. Terlebih fanatisme terhadap suatu merk banyak terjadi di masyarakat. Di kalangan masyarakat juga telah lama beredar anggapan bahwa obat yang manjur adalah obat dengan nama dagang dengan harga yang mahal (Anonim, 2002). Kondisi seperti ini sangat berbahaya, karena meskipun obat tersebut termasuk jenis obat bebas, tetap saja mempunyai efek samping yang kadang-kadang kurang diperhatikan oleh masyarakat, terutama masyarakat awam yang tidak mempunyai bekal pengetahuan tentang obatobatan. Menurut Widjajanti (1988), umumnya masyarakat kurang memahami bahwa obat selain menyembuhkan penyakit, juga mempunyai efek samping yang merugikan kesehatan. Bahaya ikatan dari obat sering timbul pada penyalahgunaan obat, misalnya terlalu sering dan sembarangan minum obat tanpa pemeriksaan dokter/nasihat dokter atau minum obat terlampau banyak/takaran yang salah. Segi-segi negatif obat perlu diketahui masyarakat. Salah satu cara yang bisa ditempuh adalah dengan menyediakan informasi yang seluas-luasnya mengenai masalah obat. Menurut Anief (1997), masalah obat pada dewasa ini berkembang sangat pesat dan rumit, oleh karena itu perlu adanya pengawasan terhadap obat agar jangan sampai timbul salah penggunaan atau penyalahgunaan. Masalah sikap pengobatan sendiri oleh masyarakat perlu menjadi perhatian, perlu adanya informasi yang benar bagi masyarakat.

Tujuan dari kegiatan ini adalah Meningkatkan pemahaman tentang penggunaan obat yang benar dan aman pada anak-anak dan remaja juga meningkatkan pengetahuan masyarakat terhadap penggunaan obat yang benar sesuai DAGUSIBU

\section{METODE}

Kegiatan penyuluhan dan pelatihan dengan mensosialisasikan gerakan masyarakat cerdas menggunakan obat (GEMA CERMAT), cara penggunaan obat yang benar "DAGUSIBU" ini dilaksanakan pada 06 Februari 2018, jam 07.30-selesai.

Bentuk kegiatan ini adalah penyuluhan dan pelatihan dengan mensosialisasikan gerakan masyarakat cerdas menggunakan obat (GEMA CERMAT), cara penggunaan obat yang benar "DAGUSIBU", bahaya dan dampaknya penyalahgunaan obat bagi kesehatan warga Winong Kelurahan Prenggan Kecamatan Kotagede Yogyakarta meliputi :

1. Penyuluhan dan pelatihan dengan mensosialisasikan gerakan masyarakat cerdas menggunakan obat (GEMA CERMAT), cara penggunaan obat yang benar "DAGUSIBU", 
2. Diskusi dan tanya jawab terkait bahaya dan dampak penggunaan obat apabila tidak sesuai dengan aturan/dosis yang dianjurkan

Sasaran dalam kegiatan ini adalah
marga Kelurahan
Prenggan Kecamatan Kotagede Yogyakarta
Metode yang digunakan adalah
pemaparan materi dan tanya jawab. Materi
yang digunakan dalam penyampaian yaitu
melalui Power Point. Pelaksanaan kegiatannya
akan dibagi dalam beberapa tahapan, antara
lain:

1. Tahap awal

Sebelum penyuluhan dimulai, perlu dilakukan proses awal yaitu peserta dikumpulkan dalam satu tempat seperti aula desa. Tujuannya adalah agar terjadi komitmen antara peserta dengan pelaksana dan lebih fokus dalam mengikuti edukasi yang akan disampaikan dan berjalan dengan lancar.

2. Tahap pembekalan materi (edukasi)

Tahapan pemberian edukasi dengan materi yang diberikan dititik beratkan pada pengetahuan tentang bahaya penggunaan obat yang baik dan benar.

3. Tahap evaluasi

Tahapan ini merupakan tahap internalisasi dari pengetahuan peserta setelah penyampaian materi. Pada tahap ini diharapkan peserta memahami apa yang disampaikan saat edukasi oleh pemateri.

\section{HASIL DAN PEMBAHASAN}

Pelaksanaan kegiatan pengabdian masyarakat dilakukan di Winong Kelurahan Prenggan Kecamatan Kotagede Yogyakarta. Pelaksanaan kegiatan bertepatan dengan kegiatan PKK yang dilakukan oleh warga Kampung Winong setiap bulan. Acara kegiatan ini berjalan dengan lancar dan tidak ada kendala. Kegiatan inipun disambut baik oleh ibu PKK karena menambah wawasan pengetahuan mereka.

Alur kegiatan dilaksanakan ketika penyuluh menjelaskan dan mensosialisasikan gerakan masyarakat cerdas menggunakan obat (GEMA CERMAT), cara penggunaan obat yang benar, bahaya dan dampaknya penyalahgunaan obat bagi kesehatan. Penyampaian materi ini dilakukan secara langsung dengan metoda ceramah yang didukung dengan LCD proyektor menampilkan materi dalam bentuk power point. Diharapkan dengan penyajian materi dapat memudahkan peserta untuk memahami materi yang disampaikanTahap kegiatan adalah sebagai berikut :

\section{Tahap Pelaksanaan Kegiatan}

1. Tahap Awal

Pada tahap ini Pelaksana dan tim dari desa setempat memberikan arahan kepada peserta untuk berkumpul di Aula desa untuk disampaikan arahan sebelum dilakukan penyampaian edukasi dan praktek lapangan.

Pelaksana kegiatan berkoordinasi dengan petugas lapangan untuk bisa mengarahkan peserta menuju area atau lokasi akan disampaikan materi.

2. Tahap Pembekalan Materi

Pada tahap ini pemateri sebelum memberikan edukasi menggunakan power point, pemateri memberikan kuesioner pengetahuan tentang pengetahuan peserta tentang penggunaan obat yang baik dan benar. Setelah selesai ada tahap pengenalan dan penyampaian materi. Materi disampaikan dengan menitik beratkan kepada pengetahuan peserta dan juga aparat desa tentang bagaimana memilih dan meminum obat yang sesuai dengan aturan. Disamping penyampaian materi juga diperlihatkan beberapa contoh.

Selanjutnya dilakukan sesi tanya jawab.

3. Tahap Evaluasi

Pada tahap ini semua peserta di kondisikan di kelompok masing - masing untuk dilaksanakan praktek atau simulasi.

Dari diskusi yang dilakukan dengan tujuan meningkatkan pemahaman masyarakat tentang penggunaan obat secara benarm meningkatkan kemandirian dan perubahan perilaku masyarakat dalam memilih, mendapatkan, menggunakan, menyimpan dan membuang obat secara benar dan meningkatkan penggunaan obat secara 
rasional. diketahui peserta sudah mengetahui dan mengenali penggolongan obat berdasarkan nama obat, bentuk sediaan, cara penggunaan, penandaan obat dalam kemasan dan efek dari obat tersebut.

Kegiatan penyuluhan dan pelatihan dilakukan menggunakan alat peraga, yaitu beberapa obat dan penandaan obat yang ada dalam kemasan obat. Pertama adalah bentuk sediaan obat, untuk obat yang diminum yaitu tablet kapsul, sirup. Obat luar seperti salep kulit, salep mata, suppositoria, obat tetes mata, obat tetes telinga. Cara penggunaan obat yang benar merupakan hal yang penting untuk mengurangi kesalahan dalam penggunaan obat. Selanjutnya dijelaskan penandaan obat yang ada di kemasan obat, antara lain obat bebas, obat bebas terbatas, obat keras dan Narkotika. Hal tersebut memberikan pengetahuan kepada masyarakat tentang cara mendapatkan obat yang benar. Selanjutnya dijelaskan tentang cara penggunaan obat yang benarm hal tersebut bisa didukung dengan membaca dan memahami informasi pada kemasan obat seperti komposisi yang terdapat dalam obat, indikasi, efek samping, dosis dan cara pakai, kontra indikasi, tanggal kadaluarsa, hal tersebut untuk mengurangi kesalahan dalam pengunaan obat serta meningkatkan penggunaan obat yang rasional. Dijelaskan pula tentang penggunaan obat secara benar, sebagai contoh adalah antibiotika, antibiotika dibeli hanya dengan resep dokter dan tidak dapat dibeli secara bebas, cara penggunaan antibiotika harus dihabiskan untuk menghindari terjadinya resistensi, pada penyakit flu dan diare tanpa sebab tidak perlu menggunakan antibiotika.

Penyuluhan tentang cara penggunaan obat seperti aturan pakai, waktu minum obat dan hal-hal yang harus diperhatikan waktu meminum obat, selain cara penggunaan obat perlu diperhatikan adalah efek samping yang timbul Ketika meminum obat dan kontra indikasi.

Penyuluhan tentang bagaimana cara penyimpanan obat dengan baik dan benar, hal tersebut untuk menjaga kualitas dari obat yang dikonsumsi dan menghindari terjadinya kerusakan dari obat. Selanjutnya adalah cara pembuangan obat yang baik, sehingga masyarakat tidak membuang obat secara sembarangan. Kegiatan diakhiri dengan sesi tanya jawab, respon masyarakat sangat baik tentang penyuluhan dan pelatihan obat tersebut.

Tabel 1 pencapaian indikator pelaksanaan kegiatan Pengabdian.

\begin{tabular}{lcc}
\hline Indikator Keberhasilan & $\begin{array}{c}\text { Sebelum } \\
\text { Pelatihan }\end{array}$ & $\begin{array}{c}\text { Setelah } \\
\text { Pelatihan }\end{array}$ \\
\hline $\begin{array}{l}\text { 100\% peserta memahami } \\
\text { pengertian Sakit }\end{array}$ & $70 \%$ & $100 \%$ \\
$95 \%$ Peserta memahami & $60 \%$ & $90 \%$ \\
akibat dari penggunaan \\
obat yang salah \\
$95 \%$ Peserta memahami \\
pentingnya penggunaan \\
obat yang baik dan \\
benar \\
$\begin{array}{l}90 \% \text { Peserta memahami } \\
\text { pentingnya }\end{array}$ \\
kesehatan menjaga \\
$90 \%$ peserta memahami \\
$\begin{array}{l}\text { apa akibat dari ketidak } \\
\text { tahuan pengelolaan obat }\end{array}$
\end{tabular}

\section{KESIMPULAN}

Banyak hal positif yang yang didapatkan dari kegiatan ini antara lainPeserta kegiatan mengetahui cara penggunaan obat yang benar, cara penyimpanan dan pembuangan obat yang benar untuk mengurangi kesalahan dalam penggunaan obat dan meningkatkan pengobatan yang rasional. Secara umum kegiatan pengabdian masyarakat yang diadakan terlaksana dengan baik dan lancar. Saran bagi Dinas Kesehatan diharapkan secara periodik melakukan pemantauan terkait penggunaan obat di masyarakat. Bagi masyarakat Winong Prenggan Kotagede Yogyakarta diharapkan masyarakat Winong Secara bijak dan cermat dalam menggunakan obat

\section{DAFTAR PUSTAKA}

Anief, M., 1991, Apa Yang Perlu Diketahui Tentang Obat 3. Gadjah Mada University Press: Yogyakarta 
Batubara, P.L. 2008. Farmakologi Dasar edisi II, Jakarta : Lembaga Studi dan Konsultasi Farmakologi

Depkes RI. 2008. Materi Pelatihan Peningkatan Pengetahuan dan Keterampilan Memilih Obat Bagi Tenaga Kesehatan. Jakarta : Depkes RI
Depkes RI. 2008. Penggolongan Obat di Indonesia.Jakarta : Depkes RI

PP IAI. 2014. Pedoman Pelaksanaan Gerakan Keluarga Sadar Obat. Pengurus Pusat Ikatan Apoteker Indonesia. Jakarta 